Oleksandr KASHCHUK

(Lwów, Uniw. im. Iwana Franki)

\title{
POWOŁANIE CZŁOWIEKA DO SZCZĘŚCIA W NAUCZANIU GRZEGORZA WIELKIEGO
}

Idea powołania człowieka do szczęścia była znana już w czasach przedchrześcijańskich. Myśliciele starożytni wyrażali ją poprzez przekonanie, że pragnienie szczęścia zostało wpisane w naturę człowieka ${ }^{1}$. Podobne poglądy odnajdujemy również w pismach Ojców Kościoła czasów późnego antyku². Celem niniejszego artykułu jest ukazanie nauki Grzegorza Wielkiego o powołaniu człowieka przez Boga do szczęścia. W przekonaniu Papieża szczęście jest zarówno powołaniem, jak i Bożym darem. Stwórca w swojej Opatrzności przeznaczył człowieka do szczęścia, którym rodzaj ludzki miał cieszyć się od początku swojego istnienia i bez końca. W pierwszej części niniejszej pracy zostanie przedstawiona koncepcja pierwotnego powołania człowieka do szczęścia. Część druga zostanie poświęcona roli Chrystusowego odkupienia w odnowie pierwotnego powołania człowieka. W ten sposób szczęście okaże się klamrą spinającą z woli Boga początek i koniec dziejów człowieka.

\section{PIERWOTNE POWOŁANIE CZŁOWIEKA DO SZCZĘŚCIA}

Grzegorz Wielki naucza, że Bóg powołując człowieka do istnienia powołał go równocześnie do przebywania w stanie szczęścia. Świadectwem tej myśli jest następująca wypowiedź Papieża:

„Człowiek został stworzony do tego, aby mógł widzieć dobro, którym jest Bóg; $[\ldots], 3$.

${ }^{1}$ Por. Plato, Euthydemus 282a; tenże, Meno 77-78; Aristoteles, Ethica nicomachea A 4, 1095a1095b; Seneca, De vita beata I 1.

${ }^{2}$ Por. Augustinus, Confessiones X 21, 31; Gregorius Magnus, Moralia VIII 18, 34; XVIII 48, 79; XXXII 10, 12.

${ }^{3}$ Gregorius Magnus, Moralia IX 33, 50, CCL 143, 491: „Ad hoc homo conditus fuit ut bonum, quod Deus est, videre potuisset". 
$\mathrm{Na}$ widzeniu Boga, czyli kontemplowaniu Jego oblicza, polega niebiańskie szczęście ${ }^{4}$, dlatego na podstawie zacytowanego zdania możemy stwierdzić, że człowiek został stworzony do szczęścia 5 .

Szczęście, do którego człowiek został w Bożym zrządzeniu powołany, miał on osiągnąć nie w dalszej perspektywie w odniesieniu do aktu stworzenia, lecz w chwili stworzenia, czyli od początku przebywania w raju. Wskazuje na to wypowiedź Autora Moraliów, że dobro zbawienia (salutis bonum) człowiek otrzymał od samego momentu stworzenia (ex ipsa [...] conditione) $)^{6}$. Zbawienie, czyli udział w wiecznej rzeczywistości utożsamia się z pozaziemskim szczęściem $^{7}$, dlatego przez dobro zbawienia należy rozumieć dobro tego szczęścia. Potwierdzeniem przekonania o doświadczaniu szczęścia przez człowieka już na etapie przebywania w raju są fragmenty Moraliów, w których czytamy, że istota ludzka wyrzucona $\mathrm{z}$ raju została pozbawiona możliwości kontemplowania Bożego oblicza ${ }^{8}$ utożsamianego $\mathrm{z}$ niebiańskim światłem ${ }^{9}$. Należy więc wyprowa-

${ }^{4}$ Por. tamże XVIII 48, 79, CCL 143A, 942: „Aspiciendo quippe aeternitatem Dei, fit eis [sanctis] ut aeterni sint; et dum visionis eius donum percipiunt, ex perceptione beatitudinis imitantur quod vident"; zob. też J.P. McClain, The Doctrine of Heaven in the Writings of Saint Gregory the Great, Washington 1956, 51: „Indeed, the vision of God is the essential element of eternal felicity”.

5 Przekonanie, że celem stworzenia człowieka jest kontemplowanie Stwórcy, decydujące o pozaziemskim szczęściu, znajduje potwierdzenie w innych wypowiedziach analizowanego dzieła; por. Gregorius Magnus, Moralia VIII 18, 34; VII 2, 2; zob. G.R. Evans, The Thought of Gregory the Great, Cambridge 1986, 61. Grzegorz Wielki naucza, że człowiekowi stworzonemu na obraz Boży i przeznaczonemu do Jego kontemplowania, zostało w naturę wpisane pragnienie Boga, zob. Gregorius Magnus, Moralia XXXII 10,12; S. Rosik, Dązenie do nieba jako nakaz historiozbawczy w doktrynie Grzegorza Wielkiego, RTK 22 (1975) z. 3, 33-43; tenże, Finalizm życia chrześcijańskiego w świetle twórczości papieża Grzegorza Wielkiego, Lublin 1980, 199-205; M. Casey, Spiritual Desire in the Gospel Homilies of Saint Gregory the Great, „Cistercian Studies” 16 (1981) 299-300.

${ }^{6}$ Por. Gregorius Magnus, Moralia XXXV 17, 44, CCL 143 B, 1805: „Nunc quippe opus est virtute patientiae, laboriosa eruditione doctrinae, castigatione corporis, assiduitate precis, confessione delictorum, inundatione lacrymarum; quorum profecto omnium conditus homo non eguit, quia salutis bonum ex ipsa sua conditione percepit. [...] Nunc ergo maioribus studiis utimur, cum salutem nequaquam servamus habitam, sed reparare curamus ablatam”.

7 Por, tamże XXXV 17, 44.

${ }^{8}$ Por. tamże XVIII 41, 66, CCL 143 A, 931: ,[...] proiectumque se a vultu oculorum Dei doluit [homo], quia in comparatione lucis intimae graviores senserat exsilii sui tenebras quas tolerabat"; zob. R. Bélanger, Anthropologie et parole de Dieu dans le Commentaire de Grégoire le Grand sur le Cantique des Cantiques, w: Grégoire le Grand. Colloques internationaux du Centre National de la Recherche Scientifique, red. J. Fontaine - R. Gillet - S. Pellistrandi, Paris 1986, 245-246.

${ }^{9}$ Por. Gregorius Magnus, Moralia XI 43, 59, CCL 143 A, 619: „Humanum genus contemplationem lucis intimae habuit in paradiso; sed sibimetipsi placens, quo a se recessit, lumen conditoris perdidit, eiusque faciem". Poznanie Bożej natury w niebiańskiej kontemplacji określa więc nasz Autor jako oglądanie jasności i światła. Papież zwraca uwagę, że Bóg jest tym, co posiada: jest Światłem, ponieważ posiada światło i jest Jasnością, ponieważ posiada jasność; por. tamże XVI 43, 54, CCL 143 A, 830: „Deus namque hoc est quod habet [...]. Lucem habet, sed lux sua ipse est. Claritatem habet, sed ipse est claritas sua. Non est ergo in eo aliud esse, et aliud habere"; zob. tamże XVIII 54, 90; McClain, The Doctrine, s. 32-33. 
dzić wniosek, że człowiek znajdując się w raju doświadczał stanu kontemplacji Boga, który jest dla niego szczęściem. Należy również przytoczyć przekonanie Papieża, że sprawiedliwi ludzie pragną odzyskać stan niebiańskiego szczęścia (ad statum beatitudinis redire $)^{10}$. Termin ,odzyskać” (redire) w odniesieniu do wiecznego szczęścia świadczy o tym, że człowiek już kiedyś był uczestnikiem tego rodzaju szczęścia. Człowiek w żadnej innej rzeczywistości nie mógł doświadczać tego szczęścia, jak tylko w raju, dlatego należy stwierdzić, że powyższy zwrot Grzegorza określa szczęściem rajskie doświadczanie człowieka ${ }^{11}$. W tym miejscu nie będziemy rozwijać tematu utraty rajskiego szczęścia, zostanie on omówiony nieco później.

Zgodnie z nauczaniem Grzegorza Wielkiego, pierwszy obdarowany szczęściem człowiek został przez Boga uzdolniony do bliskiej łączności z Nim. Bóg podarował człowiekowi samego siebie jako swoiste mieszkanie, w którym człowiek miał przebywać. Biskup Rzymu jest przekonany, że Bóg, nieograniczony miejscem (non localis), stał się miejscem (locus) dla człowieka, którego stworzył, aby trwał w Nim (in semetipso consistere) ${ }^{12}$. Ukazany pogląd znajduje odzwierciedlenie w innej wypowiedzi Papieża, że człowiek wyrzucony z raju oddalił się od zamieszkiwania w prawdziwym świetle (ab inhabitatione veri luminis elongare $)^{13}$. Prawdziwe światło, jak powiedzieliśmy, utożsamia się z Bogiem. Opuszczenie więc zamieszkiwania w prawdziwym świetle oznacza oddalenie się od zamieszkiwania w Bogu. Według naszego Autora, człowiek w raju obcował także $\mathrm{z}$ aniołami ${ }^{14}$.

Omawiając temat rajskiego szczęścia wydaje się słuszne zatrzymać się nad krótką charakterystyką stanu natury pierwszych ludzi jako podmiotu tego szczęścia. Papież naucza, że rodzaj ludzki przebywał w rajskim szczęściu w stanie wolności od skażenia swojej natury (incorruptionis libertas) ${ }^{15}$. W przeciwieństwie do doświadczanych po wyrzuceniu z raju wewnętrznych niepoko-

${ }^{10}$ Por. Gregorius Magnus, Moralia VII 3, 3.

11 Aby ostatecznie potwierdzić słuszność wyprowadzonego wniosku, stwierdzającego, że stan, w jakim człowiek został stworzony i w jakim przebywał w raju, Grzegorz uważa za szczęście, należy odwołać się do sformułowań, w których ukazuje on wprost, że rodzaj ludzki wypędzony z raju został pozbawiony szczęścia: ,,a quanta beatitudine ad quae corruptionis suae tormenta cadere” (Moralia VII 5, 5); ,, ab aeternis gaudiis cadere” (Moralia XVIII 41, 66); ,, a paradisi gaudiis cadere” (Moralia VII 6, 6); ,,a paradisi gaudiis expulsus” (Moralia VIII 30, 49; IX 33, 50); ,ab internis gaudiis deiectus” (Moralia VII 2, 2); „proiectus [...] a paradisi gaudiis” (Moralia V 29, 52); „expulsus ab internis gaudiis” (Moralia XVIII 41 ,66; IX 13, 20); „repulsus a paradisi gaudiis” (Moralia XXIV 4, 7); ,,a paradisi gaudio exire” (Moralia XXXV 14, 28); ,veras interni gaudii divitias amittere" (Moralia XXXIV 3, 5).

12 Por. Gregorius Magnus, Moralia VIII 19, 35.

13 Por. tamże VIII 18, 34.

14 Por. tenże, Dialogi IV 1; zob. Bélanger, Anthropologie et parole, s. 246; J. Lachowicz, Angelologia św. Grzegorza Wielkiego, ,Studia Teologiczne” 12 (1994) 175.

15 Por. Gregorius Magnus, Moralia VIII 32, 52. 
jów, wypływających ze słabości ludzkiej natury, doświadczał on pokoju (quietis silentium, pax silentii) ${ }^{16}$. Odzwierciedleniem tego przekonania jest fragment, w którym Grzegorz pisze, że pierwotny człowiek dobrze przez Boga stworzony (bene conditus) przez wewnętrzny pokój (quietus) mógł być w posiadaniu własnego ciała w znaczeniu całkowitego panowania nad nim ${ }^{17}$. Doświadczając pokoju człowiek cieszył się stanem trwałości umysłu (mentis status, incommutabilitatis status $^{18}$, stans mens $^{19}$ ). Nie odczuwał też upływu czasu (lapsus), ponieważ czas mijał, a on trwał (tempora, eo stante, transiebant $)^{20}$. Przez upływ czasu (augmenta temporum) jego życie mogło tylko wydłużać się (tendere), ale nie mijać (evolvere) ${ }^{21}$. Został on stworzony jako nieśmiertelny (immortalis), ale pod takim warunkiem, że jeżeli zgrzeszy, to umrze ${ }^{22}$. Na podstawie powyższych sformułowań możemy stwierdzić, że w rzeczywistości rajskiego szczęścia pierwotny człowiek doświadczał stanu nieskazitelności swojej natury. Ze względu jednak na możność zgrzeszenia człowiek mógł to szczęście utracić.

W przekonaniu Grzegorza Wielkiego rajskie szczęście, narażone na utratę przez możliwość popełnienia grzechu, nie było ostatecznym celem zaplanowanym przez Boga dla człowieka. Nie był to etap najdoskonalszy, gdyż szczęście doświadczane w raju można było przez rozwinięcie doprowadzić do pełni. Przekonanie to znajduje odzwierciedlenie w jednym z fragmentów Moraliów, w którym czytamy:

,jeżeli w raju człowiek zachowałby wierność wobec otrzymanego od Boga przykazania, dotarłby do wiecznego szczęścia” (aeterna beatitudo ${ }^{23}$.

Przytoczone zdanie ukazuje więc, że w rzeczywistości rajskiej, którą na podstawie konkretnych wypowiedzi uznaliśmy za stan rajskiego szczęścia, człowiek miał możliwość osiągnąć jeszcze wyższy stan szczęścia. Na tej podstawie należy

16 Por. tamże IV 28, 54.

17 Por. tamże VIII 6, 8,

18 Por. tamże IV 12, 23.

19 Por. tamże VIII 10, 19; zob. Bélanger, Anthropologie et parole, s. 246.

${ }^{20}$ Por. Gregorius Magnus, Moralia XI 50, 68.

21 Por. tamże IX 33, 50.

22 Por. tamże IV 28, 54; zob. L. Nieścior, Implikacje moralne nauki o czasie w „Moraliach” św. Grzegorza Wielkiego, TPatr 2 (2005) 68. W tym kontekście śmierć oznacza u Grzegorza Wielkiego oddalenie się od prawdziwego życia, polegającego na łączności z Bogiem przez kontemplowanie Go, a więc od prawdziwego szczęścia. Nie oznacza to jednak śmierci bytowej rodzaju ludzkiego. Człowiek, zdaniem Papieża, może utracić tylko szczęśliwe istnienie (beate vivere), czyli życie z Bogiem. Bytowego istnienia (essentialiter [...] vivere) utracić nie można; zob. też. Gregorius Magnus, Moralia IV 1, 5; Nieścior, Implikacje moralne, s. 67; por. Augustinus, Enarrationes in Ps. 70, 2, 3; tenże, De Trinitate IV 3, 5; zob. B.E. Daley, The Hope of the Early Church. A Handbook of Patristic Eschatology, Cambridge 1991, 136.

${ }^{23}$ Por. Gregorius Magnus, Moralia XXXV 14, 28, CCL 143 B, 1792: „Unde et primus homo praeceptum quod servaret accepit, cui se si vellet oboediens subdere, ad aeternam beatitudinem sine labore perveniret". 
przyjąć, że Bóg powołał człowieka do szczęścia pełniejszego od szczęścia rajskiego. Potwierdzeniem tego poglądu może być wypowiedź Autora Moraliów, że człowiek w raju znajdował się w takim położeniu, że jeżeliby zachował posłuszeństwo wobec Boga, przeszedłby do niebiańskiego szczęścia (beatitudo, caelestis angelorum patria) ${ }^{24}$. Podobnie w innym miejscu Grzegorz pisze, że człowiek mógłby rozkoszować się (perfrui) stanem niebiańskiej chwały (caelestis gloriae status), jeżeli nie zechciałby zgrzeszyć w raju ${ }^{25}$.

Zdaniem Grzegorza Wielkiego, człowiek osiągnąłby ten najwyższy rodzaj szczęścia z zasługi wolnej woli (ex merito liberi arbitrii) ${ }^{26}$, czyli musiałby podjąć wysiłek w celu jego nabycia. Stwierdzenie, że człowiek, jeżeli w raju zachowałby wierność wobec Boga, do wiecznego szczęścia dotarłby bez trudów (sine labo$r e)^{27}$ wskazuje, że ten wysiłek nie sprawiałby przykrości. Papież także naucza, że do wyższego rodzaju szczęścia pierwszy człowiek przeszedłby bez cielesnej śmierci. Dowodzi też, że rzeczywistości tego najwyższego rodzaju szczęścia, w odróżnieniu od rzeczywistości szczęścia rajskiego, nie można byłoby opuścić, ponieważ nie można w niej umrzeć (mori) ze względu na niemożliwość zgrzeszenia (peccare $)^{28}$. Należy przyznać, że na podstawie tekstów stwierdzających istnienie wyższego rodzaju szczęścia w porównaniu ze szczęściem rajskim, trudno wyróżnić inne elementy wskazujące na wyższość tego drugiego rodzaju szczęścia, oprócz przekonania o niemożliwości zgrzeszenia w nim.

Według Autora Moraliów, rodzaj ludzki nie tylko nie potrafił osiągnąć wyższego rodzaju szczęścia, ale nawet opuścił, jak już zaznaczaliśmy, szczęście rajskie, które posiadał ${ }^{29}$. Papież utrzymuje, że opuszczenie szczęścia przez pierwszego człowieka odbyło się z własnej woli ${ }^{30}$ : dobrowolnie nie zachował on posłuszeństwa wobec Stwórcy ${ }^{31}$. Wbrew przykazaniu danemu mu przez Boga, dotknął zabronionego owocu ${ }^{32}$. Przekroczenie otrzymanego przykazania Grzegorz Wielki uważa za ciężką winę (gravis culpa) ${ }^{33}$, która spowodowała

${ }^{24}$ Por. tamże IV 28, 54.

25 Por. tamże XVIII 41, 66, CCL 143A, 931: ,[...] luget [homo] exsilium quod damnatus patitur, et suspirat ad caelestis gloriae statum, quo perfrui securus posset si peccare noluisset”. Stan tego wyższego rodzaju szczęścia jest utożsamiany przez Papieża z niebiańską rzeczywistością, udostępnioną sprawiedliwym ludziom przez Chrystusowe odkupienie, zob. tamże IV 28, 54; IV 29, 56. Nad omówieniem tematu odkupienia zatrzymamy się później.

${ }^{26}$ Por. tamże IV 28, 54.

27 Por. tamże XXXV 14, 28.

${ }^{28}$ Por. tamże IV 28, 54.

${ }^{29}$ Por. tamże VII 5, 5; IX 33, 50; V 29, 52; XVIII 41, 66; XXIV 4, 7; VII 6, 6; VIII 30, 49; XXXV 14, 28; XVIII 41, 66; IX 13, 20; VII 2, 2; XXXIV 3, 5; XXV 8, 20; zob. Evans, The Thought, s. 64 .

${ }^{30}$ Por. Gregorius Magnus, Moralia XVII 29, 44; VIII 6, 8.

31 Por. tamże VIII 18, 34.

32 Por. tamże IX 33, 50.

${ }^{33}$ Por. tamże XXIV 4, 7. 
odejście od rajskiego szczęścia ${ }^{34}$. Przez opuszczenie raju człowiek zamienił stan otrzymany w akcie stworzenia (status conditionis) $)^{35}$ na cierpienie skażenia (corruptionis [...] tormenta $^{36}$, aerumna corruptionis ${ }^{37}$ ) doświadczane w życiu ziemskim $^{38}$.

Od tej pory dostęp do wiecznego szczęścia został przed człowiekiem zamknięty. Utracił on zdolność zrealizowania pierwotnego powołania do szczęścia. Chociaż odznaczałby się on wielką sprawiedliwością życia, po cielesnej śmierci musiał wstępować do otchłani (inferni claustra) ${ }^{39}$. Tam sprawiedliwy człowiek odpoczywał w oczekiwaniu na odnowienie zdolności wejścia do niebiańskiego królestwa ${ }^{40}$. Odpoczynek ten charakteryzował się niezaspokojo-

${ }^{34}$ Por. tamże VII 2, 2.

${ }^{35}$ Por. tamże VIII 6, 8.

36 Por. tamże VII 5, 5; zob. Evans, The Thought, s. 64.

37 Por. Gregorius Magnus, Moralia VII 2, 2; zob. Bélanger, Anthropologie et parole, s. 246247.

${ }^{38}$ Poglądy Grzegorza Wielkiego na temat przeznaczenia pierwotnego człowieka przez Boga do uszczęśliwiającego obcowania z Nim w raju oraz dobrowolnego opuszczenia tego stanu przez człowieka utrzymują się w nurcie myśli biblijno-patrystycznej. W Piśmie Świętym odzwierciedlenie tej doktryny znajdujemy przede wszystkim w początkowych fragmentach Księgi Rodzaju (Rdz 1, 26 - 3, 24) i w nauczaniu św. Pawła ( Rz 5, 12-21; 1 Kor 15, 45-49). Prawda o pierwotnym stanie człowieka, zawarta w Biblii, była przedmiotem interpretacji większości autorów epoki patrystycznej, szczególnie piszących w języku greckim: Ireneusza z Lyonu (por. Adversus haereses III 18; V 6 i 16; IV 37-38; zob. J.N.D. Kelly, Początki doktryny chrześcijańskiej, tłum. J. Mrukówna, Warszawa 1988, 133), Klemensa Aleksandryjskiego (por. Stromata II 19, 98; III 17, 102; II 22, 131; VI 12, 96), Atanazego Aleksandryjskiego (por. Oratio contra gentes 3; zob. Kelly, Początki doktryny, s. 258); Ojców Kapadockich (por. Basilius Magnus, Homiliae VIII 3, 5; Gregorius Nazianzenus, Orationes XLV, 8; Gregorius Nyssensis, Oratio catechetica magna 6; zob. Kelly, Poczatki doktryny, s. 259260). Grzegorz Wielki korzystał jednak głównie z myśli łacińskich Ojców Kościoła. Na Zachodzie problematykę utraconego przez człowieka stanu pierwotnej nadprzyrodzonej szczęśliwości poruszali między innymi: Tertulian (por. Adversus Marcionem II 5-9), Hilary z Poitiers (por. Tractatus super Psalmos 2, 15; 59, 4; 118) i Ambroży z Mediolanu (por. Expositio Psalmi 118, 7, 8; 15, 36; Enarrationes in Ps. 43, 75; Expositio Evangelii secundum Lucam VII 142; De paradiso IX 42; XIII 63). W sposób szczególny rozwijał ją św. Augustyn, do którego przede wszystkim nawiązywał Autor Moraliów. Biskup Hippony utrzymywał, że Adam trwał w stanie pierwotnego szczęścia, w którym posiadał możność niegrzeszenia. Jego ciało było uduchowione, poddane panowaniu duszy, podporządkowanej Bogu. Pierwotny człowiek jednak jako istota stworzona i zmienna z natury, przez niewłaściwe używanie wolnej woli za namową zazdroszczącego mu szatana, popełnił grzech i odwrócił się od Boga. Skutkiem tego grzechu było pozbycie się rajskiego szczęścia, które objęło cały rodzaj ludzki (por. Augustinus, De correptione et gratia 33; De Genesi ad litteram VIII 12, 25; VI 25, 36; De civitate Dei XIII 20; XIV 13; XII 8; De peccatorum meritis et remissione II 22, 36; De Genesi contra Manichaeos II 8, 10; Enarrationes in Ps. 48, 2, 2; Opus imperfectum contra Iulianum VI 22; zob. Kelly, Początki doktryny, s. 269; A. Słomkowski, Pierwotny stan człowieka wedtug nauki św. Augustyna, Lwów 1933, 51-55).

39 Por. Gregorius Magnus, Moralia XII 9, 13; XX 34, 66; XIII 43, 48; IV 29, 56; zob. tenże, Homiliae in Evangelia I 19, 4; por. McClain, The Doctrine, s. 19.

${ }^{40}$ Por. Gregorius Magnus, Moralia IV 29, 56; XIII 44, 49; zob. McClain, The Doctrine, s. 19; Nieścior, Implikacje moralne, s. 69-70. 
nym pragnieniem Boga ${ }^{41}$, ponieważ pozbawienie oglądania oblicza Bożego po cielesnej śmierci było dla sprawiedliwych ludzi bolesne ${ }^{42}$.

Na wolny wybór człowieka, decydujący o opuszczeniu raju, miał wpływ diabeł. Papież pisze, że ciężką winę (gravis culpa), polegającą na niedotrzymaniu posłuszeństwa wobec Boga, pierwszy człowiek popełnił za namową diabła (serpentis suasio $)^{43}$. Diabeł odrzucony od rzeczywistości niebiańskiego szczęścia (beatitudo), uznał siebie za mniejszego od człowieka doświadczającego szczęścia. Zazdroszcząc szczęśliwemu człowiekowi podkradł się do niego i nakłonił go do popełnienia grzechu ${ }^{44}$, którego skutkiem było utracenie szczęścia ${ }^{45}$.

\section{ODKUPIENIE CZŁOWIEKA ODNOWIENIEM PIERWOTNEGO POWOEANIA DO SZCZEŚCIA}

Zgodnie z nauczaniem Grzegorza Wielkiego, ze strony Boga propozycja szczęścia dla człowieka pozostała aktualna także po zawinionym przez niego

${ }^{41}$ Por. Gregorius Magnus, Moralia XIII 46, 51.

${ }^{42}$ Por. tamże XIII 44, 49; tenże, Homiliae in Evangelia I 19, 4; zob. McClain, The Doctrine, s. $19-20$.

43 Por. Gregorius Magnus, Moralia XXIV 4, 7; XII 6, 9; VIII 19, 35; XXXIV 23, 47.

${ }^{44}$ Por. tamże V 46, 84.

45 Wyjaśnienia wymaga zagadnienie utraty niebiańskiego szczęścia przez szatana. W przekonaniu Grzegorza Wielkiego diabeł został stworzony przez Boga do bytowania w niebiańskim szczęściu (in beatitudine conditus, por. Moralia II 17,32) jako jeden z niebiańskich duchów (unus [...] ex caelestibus spiritibus, por. Moralia XXXII 24, 50), jako najwyższy spośród innych anielskich duchów (praelatus ceteris legionibus, summus, por. Moralia XXXII 23, 47; XXXII 24, 50), jako wielki bez porównania (magnus sine comparatione, por. Moralia XXXII 23, 47; zob. Evans, The Thought, s. 62). Nie chciał on jednak podporządkować się Bogu (subesse, por. Moralia XXXIV 21, 40). Pragnął być wyższym od wszystkich (praeesse ceteris, appetitum [...] celsitudinis, praeesse per gloriam quaerere, por. Moralia XXXIV 21, 40-41). Przez tę pychę (superbia) został pozbawiony niebiańskiego szczęścia (beatitudinis gloria; vita [...] beatitudinis; arx beatitudinis; internae felicitatis beatitudo, por. Moralia IV 1, 5; XXXIV 23, 47; XXXIV 7, 12; XXXIV 20, 39; zob. Evans, The Thought, s. 62-63). Stworzony jako najwyższy, został potępiony (damnatus) przez Boga bez przebaczenia (sine venia, por. Moralia XXXII 23, 47; zob. Evans, The Thought, s. 62). Chociaż diabeł opuścił niebiańskie szczęście, nie utracił bytowego istnienia (naturae essentia, por. Moralia XIV 18, 22; IV 1, 5) oraz potęgi swojej natury (naturae [...] magnitudo, naturae potentia, por. Moralia XXXIV 20, 39; II 4, 4), której mocą może przezwyciężyć to, co ludzkie. Nie udało mu się jednak wyzwolić spod Bożego panowania (por. Moralia XXXIII 22, 41). Zdaniem Papieża, wraz z diabłem wieczne szczęście opuściła wielka ilość nieczystych duchów (immundorum spirituum multitudo, por. Moralia II 49, 76; XIX 2, 4; XXXIV 7, 12-13). Ich upadek oczyścił (purgare) wspólnotę aniołów (por. Moralia XXXIV 7, 12-13), ponieważ po odejściu złych duchów pozostały tylko dobre anielskie duchy wierne Bogu, aby w sposób szczęśliwy żyć na wieki (beate in aeternum vivere; sine felicitatis fine, por. Moralia XXXIV 7, 12-13; XXVII 39, 65). Jednakże niebiańską wspólnotę aniołów na skutek odejścia części z nich Grzegorz Wielki uważa za niepełną pod względem ilości (per numeri quantitatem praerupti, por. Moralia XXXI 49, 99; zob. McClain, The Doctrine, s. 107). 
utraceniu zdolności zrealizowania pierwotnego powołania. Człowiek jednak o swoich siłach nie mógł odzyskać utraconego szczęścia ${ }^{46}$. Diabeł jakby zgodnie z prawem (quasi iuste) trzymał ludzi w swojej niewoli na skutek grzechu pierwszych rodziców, którzy dobrowolnie poddali się jego niewoli ${ }^{47}$. Wyzwolenie z niewoli mogło się dokonać jedynie przez ofiarę, którą miał złożyć z siebie człowiek nieskażony grzechem. Wśród zwykłych ludzi nie można było znaleźć osoby bez grzechu. Konieczne więc było działanie Boże, przez które człowiek zostałby odkupiony. Bóg pragnąc odnowić człowiekowi możliwość osiągnięcia wiecznego szczęścia, zainterweniował w osobie Chrystusa, który przyjął ludzką naturę, ale nie ludzki grzech ${ }^{48}$. Diabeł pragnął przez pokusy uwieść Jezusa, ale nie mogąc przezwyciężyć jego umysłu, postanowił zgładzić Jego ciało. W ten sposób nadużył jakby swojego prawa, ponieważ zabił ciało Chrystusa, do którego nie miał żadnego prawa z tej racji, że w Nim nie było grzechu. Niesprawiedliwie występując przeciw Bogu, sprawiedliwie utracił także prawo do ludzi, których posiadał jakby zgodnie z prawem. Chrystus poniósł więc niezasłużoną śmierć, wystawiając siebie bezgrzesznego jako ofiarę za grzechy ludzi ${ }^{49}$ : dobrowolnie umarł i zmartwychwstał w celu odkupienia człowieka ${ }^{50}$.

Grzegorz Wielki przeciwstawia pierwszego człowieka (primus homo), który chciał spełniać swoją wolę i utracił szczęście - Chrystusowi, jako drugiemu człowiekowi (secundus), który ze względu na odzyskanie rodzajowi ludzkiemu możliwości osiągnięcia niebiańskiego szczęścia, pełnił wolę nie swoją, lecz Ojca $^{51}$. Chrystus, zdaniem Grzegorza, odkupił nie tylko tych ludzi, którzy mieli się narodzić po Jego przyjściu na świat, ale także ludzi sprawiedliwych, którzy umarli cieleśnie przed Jego wcieleniem. Według Papieża, Chrystus zstępując do otchłani (inferni claustra) zniszczył moc piekła ${ }^{52}$ i wyprowadził stamtąd dusze sprawiedliwych ludzi, które tam przebywały ${ }^{53}$.

${ }^{46}$ Por. Gregorius Magnus, Moralia XII 9, 13.

47 Por. tamże XVII 30, 46, CCL 143A, 877-878: „Ipse namque diabolus in illa nos parentis primi radice supplantans, sub captivitate sua quasi iuste tenuit hominem, qui, libero arbitrio conditus, ei iniusta suadenti consensit. Ad vitam namque conditus in libertate propriae voluntatis, sponte sua factus est debitor mortis".

${ }^{48}$ Por. tamże XVII 30, 46.

${ }^{49}$ Por. tamże XVII 30, 47.

50 Por. tamże XXXI 52, 104.

51 Por. tamże XXXV 14, 28.

52 Por. tenże Homiliae in Evangelia II 21, 7.

53 Por. tenże Moralia XII 10, 14; XXIX 12, 23; IV 29, 56; XIII 43, 48; XVIII 35, 54. Doktryna zstąpienia Chrystusa do otchłani jest typowo judeochrześcijańska. Chodziło w niej o wykazanie uniwersalności zbawienia, ogłoszonego także umarłym sprawiedliwym ludziom, oraz realności śmierci Jezusa. Według tej idei w otchłani Chrystus przepowiadał zbawienie sprawiedliwym, którzy się tam znajdowali. Było to całkowite zwycięstwo Chrystusa odniesione nad śmiercią w miejscu, gdzie przebywają ofiary śmierci, zob. Ignatius, Ad Magnesios IX 2; Hermas, Pastor IX 16, 2-7; Irenaeus, Adversus haereses IV 27, 2; Clemens Alexandrinus, Stromata II 9, 43; VI 6, 45; Origenes, Commentarium in Epistulam ad Romanos V 10; por. J. Daniélou, Teologia judeochrześ- 
Papież mocno podkreśla, że przyjście Chrystusa, odnawiającego człowiekowi zdolność osiągnięcia niebiańskiego szczęścia, było wielkim darem od Boga udzielonym z łaski (gratia). Uczynki rodzaju ludzkiego zasługiwały nie na przybycie Chrystusa, lecz na ludzkie cierpienie (supplicia). Na co innego człowiek zasłużył ze sprawiedliwości, a co innego otrzymał z daru łaski ${ }^{54}$. Chrystus objawiając się człowiekowi w ciele kroczył śladem człowieka jako zbiega, który opuścił Boga jako swoiste mieszkanie. W tym objawieniu się niejako samo mieszkanie (locus) przyszło do utraconego człowieka, aby go powstrzymać 55 .

W Chrystusowym przyjściu na świat, otwierającym człowiekowi wejście do niebiańskiego szczęścia, Autor Moraliów zwraca także uwagę na przykład osobistego życia Jezusa, przez który przemienił On człowieka (ostenso exemplo commutare). Chrystus przyjmując ludzkie ciało, identyczne z tym, w którym człowiek prowadzi ziemskie życie, ujawnił równocześnie inne nieznane dotąd życie pozaziemskie. Przez osobisty przykład ukazał, że życia przed cielesną śmiercią nie należy miłować, lecz znosić je ze względu na życie po śmierci ciała $^{56}$. Umierając - Chrystus nauczył nie bać się śmierci, zmartwychwstając - mieć zaufanie w życie wieczne, a wstępując do nieba - radować się przyszłym udziałem w niebiańskiej ojczyźnie ${ }^{57}$. Przykład Chrystusa był konieczny, aby człowiek miał nadzieję, że pewnego dnia jego ciało zmartwychwstanie $e^{58}$.

Podkreślając wielkość udzielonego człowiekowi przez przyjście Chrystusa daru szczęścia Grzegorz Wielki zwraca uwagę, że człowiek jako ten, który wzgardził Bogiem i naśladował diabła, przez Chrystusowe odkupienie nie tylko powrócił do stanu, w jakim został stworzony (status conditionis), lecz nawet został wywyższony do większej chwały (gloriosius exaltatur). Utracił on raj (paradisus), a otrzymał niebo (caelum), czyli niebiańskie szczęście, które jest wznioślejsze od rajskiego ${ }^{59}$. O umożliwieniu ludziom sprawiedliwym wejścia do niebiańskiej rzeczywistości świadczą też teksty, które mówią, że Chrystus zstąpił do otchłani (claustra inferni) i wyprowadził stamtąd

cijańska, tłum. S. Basista, Kraków 2002, 260-275; H. Pietras, Początki teologii Kościoła, Kraków 2000, 25-26; B. Sesboüé, Treść tradycji: reguła wiary i symbole (II-V wiek), w: Historia dogmatów, red. B. Sesboüé, t. 1: B. Sesboüé - J. Wolinski, Bóg zbawienia, tłum. P. Rak, Kraków 1999, 106-107; G. Minois, Historia piekła, tłum. A. Dębska, Warszawa 1996, 84-89.

${ }^{54}$ Por. Gregorius Magnus, Moralia XVIII 40, 62.

55 Por. tamże VIII 19, 35.

56 Por. tamże XXX 24, 69; zob. Evans, The Thought, s. 66-68.

57 Por. Gregorius Magnus, Moralia XXVII 15, 29; zob. McClain, The Doctrine, s. 83.

${ }^{58}$ Por. Gregorius Magnus, Moralia XIV 55, 68; zob. tenże, Homiliae in Evangelia II 21, 6; McClain, The Doctrine, s. 83-84.

59 Por. Gregorius Magnus, Moralia XXVII 15, 30, CCL 143B, 1353-1354: „Sed valde mira sunt ista, valde terribilia, quod homo in terra editus, atque a caelesti patria exigentibus meritis longe damnatus, non solum ad statum conditionis reducitur, sed etiam gloriosius exaltatur, ut qui paradisum perdidit caelum recipiat". 
ludzi sprawiedliwych do nieba (caelestia) ${ }^{60}$. Od tej pory sprawiedliwi ludzie przyjmują niebiańskie szczęście (aeternae retributionis gaudia), gdy tylko opuszczają ciało o ziemskich właściwościach ${ }^{61}$. Człowiek, zdaniem naszego Autora, nie może dotrzeć do nieba w tym ciele, trzymającym go w skażonej rzeczywistości i stąd konieczne jest rozłączenie się z nim ${ }^{62}$. Dlatego Grzegorz stwierdza, że sprawiedliwi ludzie docierają do niebiańskiego szczęścia w dniu cielesnej śmierci (dies mortis) ${ }^{63}$. Papież zwraca jednak uwagę, że od razu po śmierci, do nieba może wstąpić dusza tylko doskonale sprawiedliwego człowieka, który popełnił bardzo lekkie grzechy ${ }^{64}$. Dla innych osób, które popełniły większe, ale nie ciężkie grzechy, w życiu pozaziemskim istnieje czas oczyszczenia jako naturalny i konieczny warunek wejścia do nieba. W tym przekonaniu rozwijającym naukę Augustyna ${ }^{65}$, Grzegorz Wielki jest jednym z fundatorów doktryny o czyśćcu ${ }^{66}$.

W związku z przekonaniem o wyższości szczęścia darowanego przez Chrystusa od szczęścia rajskiego, należy zwrócić uwagę, że Autor Moraliów nie zawsze jest konsekwentny w stwierdzeniach dotyczących tego tematu. W jednej ze swoich wypowiedzi głosi, że Chrystus przeprowadził dusze wybranych $\mathrm{z}$ otchłani (inferni claustra) do rajskiego szczęścia (paradisi gaudia) ${ }^{67}$, a więc do stanu, jaki człowiek posiadał w raju, a nie do stanu wyższego, który miał

${ }^{60}$ Por. tamże XXIX 12, 23; IV 29, 56; XIII 43, 48; XVIII 35, 54.

${ }^{61}$ Por. tamże, XXIV 11, 34; XIII 43, 48, zob. Augustinus, De civitate Dei XX 9; tenże, Confessiones IX 3, 6; tenże, Epistula 164, 8; 187, 3, 7; por. Daley, The Hope, s. 137-138.

${ }^{62}$ Por. Gregorius Magnus, Moralia IV 25, 46; IV 28, 54.

${ }^{63}$ Por. tamże XII 4, 5; IV 29, 56; XXIV 11, 34; zob. tamże XXXV 14, 25; IV 25, 46; por. McClain, The Doctrine, s. 20-23; G. Cremascoli, „Novissima hominis” nei „Dialogi” di Gregorio Magno, Bologna 1979, s. 72-73; Daley, The Hope, s. 213. Należy zaznaczyć, że zgodnie z nauczaniem Autora Moraliów, sprawiedliwy człowiek będzie miał udział w niebiańskim szczęściu na dwóch etapach. Najpierw po cielesnej śmierci, a przed powszechnym zmartwychwstaniem cial, niebiańskiego kontemplowania Boga będzie doświadczać sama dusza człowieka. Po zmartwychwstaniu zaś udział w kontemplowaniu Stwórcy będzie miała ludzka dusza połączona z nieskazitelnym ciałem, por. Gregorius Magnus, Moralia Praefatio X 20; XXXV 14, 25; IX 11, 17, zob. McClain, The Doctrine, s. 78-83 i 99-100; Daley, The Hope, s. 213; L.F. Ladaria, Kres człowieka i kres czasów, w: Historia dogmatów, red. B. Sesboüé, t. 2: V. Grossi - L.F. Ladaria - Ph. Lécrivain - B. Sesboüé, Człowiek i jego zbawienie, thum. P. Rak, Kraków 2001, 381.

${ }^{64}$ Por. Gregorius Magnus, Dialogi IV 19; tenże, Moralia XXIV 11, 34; zob. McClain, The Doctrine, s. 23-25.

${ }^{65}$ Por. Augustinus, Confessiones IX 13, 35-36; zob. R.R. Atwell, From Augustine to Gregory the Great an evaluation of the emergence of the doctrine of purgatory, JEH 38 (1987) 175-176; Daley, The Hope, s. 138-139.

${ }^{66}$ Por. Gregorius Magnus, Dialogi IV 26; IV 41; tenże, Moralia XII 21, 26; tenże, Homiliae in Evangelia II 32, 8, zob. Atwell, From Augustine, s. 177-179; C. Vogel, Deux conséquences de l'eschatologie grégorienne: la multiplication des messes privées et les moines-prêtres, w: Grégoire le Grand, s. 267-276; McClain, The Doctrine, s. 24-25; Cremascoli, , Novissima hominis”, s. 105-118; Z. Kijas, Czyściec. Czy jest i dla kogo?, Kraków 1999, 113-120; Daley, The Hope, s. 214.

${ }^{67}$ Por. Gregorius Magnus, Moralia XII 10, 14, zob. tamże XII 9, 13. 
osiągnąć w dalszej perspektywie. Ostatecznie jednak należy stwierdzić, że zauważone niekonsekwencje nie zaprzeczają Grzegorzowemu przekonaniu o otwarciu człowiekowi przez Chrystusa dostępu do nieba, a nie do raju. Fragmenty, w których one występują, skupiają się bowiem nie nad precyzowaniem pozaziemskiego stanu darowanego człowiekowi po cielesnej śmierci, lecz na podkreśleniu, że człowiek został uwolniony ze stanu skażenia, z którego przedtem nie miał możliwości wyrwać się do pozaziemskiego szczęścia ${ }^{68}$.

${ }^{68}$ Poglądy Grzegorza Wielkiego, zgodnie z którymi Chrystus przez odkupienie umożliwił człowiekowi wejście do utraconego niebiańskiego szczęścia, w najważniejszych punktach są zakorzenione we wcześniejszej tradycji biblijno-patrystycznej. W Piśmie Świętym w sposób szczególny temat ten poruszył św. Paweł. Przeciwstawił on Adama, który przez nieposłuszeństwo sprowadził na rodzaj ludzki śmierć, Chrystusowi, który przez posłuszeństwo sprowadził na wszystkich ludzi usprawiedliwienie i łaskę (Rz 5, 12-21; 14, 9; 1 Kor 15, 45; Ef 5, 2; 1 Kor 15, 21-23; 1Tes 5, 10), por. B. Sesboüé, W nurcie Chalcedonu: chrystologia i soteriologia od VI wieku, w: Historia dogmatów, red. B. Sesboüé, t. 1: B. Sesboüé - J. Wolinski, Bóg zbawienia, tłum. P. Rak, Kraków 1999, 406; Z. Kijas, Niebo. Dom Ojca, Kraków 2001, 85-90. Do powyższych stwierdzeń biblijnych o zbawieniu dokonanym przez Chrystusa, którego skutkiem jest możliwość otrzymania wiecznego szczęścia, nawiązywali autorzy patrystyczni, jak Justyn (por. Apologia I 66, 2; I 32, 7; Dialogus cum Iudaeo Tryphone 134, 5; 138, 2), Ireneusz (por. Adversus haereses III 18, 7; V Praefatio; V 16, 3; III 22, 4; III 21, 10; zob. Sesboüé, W nurcie Chalcedonu, s. 402; Kelly, Poczatki doktryny, s. 133-135), Klemens Aleksandryjski (por. Quis dives salvetur? 37, 4, zob. Kelly, Początki doktryny, s. 142), Orygenes (por. Homiliae in Librum Iesu Nave VIII 3; Homiliae in Numeros 24, 1; zob. Kelly, Początki doktryny, s. 143), Atanazy Aleksandryjski (por. Orationes contra Arianos I 44; II 61; II 67) i Ojcowie Kapadoccy (por. Gregorius Nazianzenus, Orationes XXX 6; Basilius Magnus, Homiliae in Psalmos 28, 5; 48, 3; Gregorius Nyssenus, Oratio catechetica magna 22-24; zob. Sesboüé, W nurcie Chalcedonu, s. 325; Kelly, Poczatki doktryny, s. 284-287). Na Zachodzie kwestie związane ze zbawczym dziełem Chrystusa poruszali Tertulian (por. De carne Christi 6; De baptismo 11; zob. Kelly, Początki doktryny, s. 137), Cyprian (por. De opere et eleemosynis 1; De lapsis 17; zob. Kelly, Początki doktryny, s. 136137.138), Hilary z Poitiers (por. De Trinitate II 24-25; Tractatus super Psalmos 68, 23; 53, 13; 135 , 15; zob. Kelly, Początki doktryny, s. 288), Ambroży (por. Epistulae 72, 8; Expositio Evangelii secundum Lucam VII 117; IV 7; zob. Kelly, Początki doktryny, s. 288), a także Augustyn, główny inspirator myśli Grzegorza Wielkiego. Podobnie jak nasz Autor, Biskup Hippony zwracał uwagę na funkcję Chrystusa jako pośrednika między Bogiem a człowiekiem. Mówił on o krwi Chrystusa jako o cenie, która została zapłacona za człowieka poddanego w wyniku grzechu władzy diabła i którą szatan przyjął. Augustyn jednak, inaczej niż Grzegorz, nauczał, że szatan nie miał żadnych praw do rodzaju ludzkiego. Bóg wybrał sposób postępowania bardziej zgodny z własną sprawiedliwością, by szatanowi nie było odebrane panowanie siłą. Stąd męka Chrystusa oddawała Syna Bożego w ręce szatana, a kiedy ten drugi, nie znajdując w Chrystusie nic godnego śmierci, zabił Go, został słusznie zmuszony za karę do uwolnienia rodzaju ludzkiego. Stąd sprawiedliwe było, by został odpuszczony dług ludziom, którzy pozostawali we władzy diabła. Na tym właśnie, zdaniem Biskupa Hippony, polega usprawiedliwienie przez krew Chrystusową ( $\mathrm{Rz} 5,9)$. To właśnie niewinność Chrystusa nadała ekspiacyjną wartość Jego śmierci (por. Augustinus, De Trinitate IV 19; XIII 12, 16-15, 19; IV 13, 17; De civitate Dei X 20; Contra Faustum Manichaeum XIV 4; XIV 7, zob. Sesboüé, W nurcie Chalcedonu, s. 404-405; Kelly, Początki doktryny, s. 291293). Nauka Augustyna, podobnie jak Autora Moraliów, podkreśla także pedagogiczny wymiar dzieła Chrystusa, który swoim życiem dał ludziom budujący przykład (por. Augustinus, Tractatus in Ioannis Evangelium 98, 3; tenże, De fide et symbolo 6). 
Z kwestią odkupienia człowieka przez Chrystusa do możliwości osiągnięcia niebiańskiego szczęścia wiąże się temat wywyższenia godności ludzkiej natury. Papież zwraca uwagę, że Chrystus przyjmując ludzką naturę i stając się jakby mniejszym od aniołów, przez swoje uniżenie (minoratio) zrównał (aequales [...] fecit) godność człowieka z godnością anielską ${ }^{69}$. Grzegorz powołując się na Pismo Święte ukazuje niższość ludzkiej godności od godności anielskiej przed Chrystusowym wcieleniem oraz równość godności ludzkiej i anielskiej po wcieleniu. Pisze, że w czasach Starego Testamentu człowiek oddawał cześć (adorare) aniołom ( $\mathrm{Rdz} 18,2)$. W czasach zaś po przyjściu Chrystusa na świat, gdy człowiek w osobie Jana apostoła chciał oddać cześć aniołowi, został od tego powstrzymany (Ap 19, 10; 22, 9). Nasz Autor stwierdza, że aniołowie przyjmowali cześć od ludzi, ponieważ gardzili człowiekiem oddanym skażeniu i nieodkupionym od tego skażenia. Po odkupieniu jednak nie uważali już ludzkiej natury za podległą sobie (subiecta), ponieważ jako przyjęta przez Chrystusa została ona wywyższona ${ }^{70}$. Oprócz tekstów, które ukazują, że według Grzegorza, ludzka natura w Chrystusie została wywyższona do równości z aniołami, występują również takie, które ukazują, że nawet przewyższa ona godnością aniołów (praelata [...] etiam angelis ${ }^{71}$ ). Trudno jest rozstrzygnąć, za jakim przekonaniem Grzegorz ostatecznie się opowiada ${ }^{72}$.

Na zakończenie tej części artykułu trzeba zwrócić uwagę, że chociaż niebiańskie szczęście, do którego człowiek został powołany, jest, w rozumieniu Grzegorza Wielkiego, darem udzielonym człowiekowi przez Boga z łaski, człowiek nie może otrzymać przygotowanego przez Boga pozaziemskiego szczęścia, jeżeli z wolnej woli nie podejmie wysiłku dążenia do niego. Człowiek powinien odpowiedzieć właściwym sposobem postępowania na Boże wezwanie do wiecznego szczęścia, aby stać się godnym udziału w niebiańskiej rzeczywistości. Papież podkreśla, że ludzie sprawiedliwi po odkupieniu docierają do nieba $\mathrm{z}$ wielkim trudem (cum magno labore) ${ }^{73}$. $\mathrm{Z}$ tego powodu Grzegorz

69 Por. Gregorius Magnus, Moralia XXVII 15, 29, CCL 143B, s. 1352: „Is ergo qui propter nos minor angelis exstitit aequales nos angelis virtute suae minorationis fecit".

70 Por. tamże; zob. też. tenże, Homiliae in Evangelia I 8, 2; Homiliae in Hiezechielem Prophetam II 2, 15; por. McClain, The Doctrine, s. 107; Lachowicz, Angelologia, s. 175.

71 Por. Gregorius Magnus, Moralia XXVII 15, 30, CCL 143B, 1353: „Perpendat [humana fragilitas] sollicite quo caput praecessit, et quae ad vivendum praeceptis astringitur, ad sperandum exemplo roboretur; confidat caelos, speret supernam patriam, angelorum se sociam sciat, atque in suo capite praelatam se etiam angelis gaudeat”; zob. tamże XXVII 15, 29, CCL 143B, 1352: „[...] postmodum vero humanam naturam eo iam subiectam habere non poterant [angeli], quo hanc in auctore suo etiam super semetipsos ductam videbant [...]"; por. tenże, Homiliae in Evangelia I 8, 2; McClain, The Doctrine, s. 107.

72 Por. Gregorius Magnus, Moralia XXVII 15, 30.

73 Por. tamże IV 29, 56. Na temat duchowego doskonalenia chrześcijanina w nauczaniu Grzegorza Wielkiego por. O. Kashchuk, Droga doskonalenia chrześcijańskiego w nauczaniu Grzegorza Wielkiego, RBL 61 (2008) 143-153. 
Wielki uważa niebiańskie szczęście nie tylko za dar dany człowiekowi przez Boga, ale również za wynagrodzenie trudu, który człowiek podjął w celu stania się godnym przyjęcia tego daru. Świadectwem tego przekonania jest następująca wypowiedź Papieża dotycząca sprawiedliwych ludzi uczestniczących w rzeczywistości niebiańskiej:

„Zobaczymy więc Boga i On sam będzie nagrodą za nasz trud, tak że po ciemnościach tej doczesności będziemy radować się rozpalonym Jego światłem"74.

Na podstawie przytoczonego zdania możemy stwierdzić, że nagroda za ludzki trud (praemium laboris nostri) utożsamia się, zdaniem Autora, z widzeniem Boga (videbimus [...] Deum) ${ }^{75}$. Na widzeniu Boga polega niebiańskie szczęście, dlatego możemy stwierdzić, że nagroda za ludzki trud utożsamia się z wiecznym szczęściem. Uznanie niebiańskiego szczęścia za nagrodę nie pomniejsza przekonania, że to szczęście jest niezasłużonym Bożym darem.

Podsumowując niniejszy artykuł należy stwierdzić, że w nauczaniu Grzegorza Wielkiego człowiek został powołany przez Stwórcę do szczęścia, które równocześnie zostało mu dane jako dar. Od początku swojego istnienia człowiek przebywał w rajskim szczęściu, $\mathrm{z}$ którego w perspektywie miał przejść do jeszcze wyższego stanu szczęścia. Człowiek jednak, nie zachowując posłuszeństwa wobec Boga, nie tylko nie dotarł do tego wyższego rodzaju szczęścia, ale nawet utracił szczęście, które posiadał w raju. Od tej pory dostęp do pozaziemskiego szczęścia został przed nim zamknięty i nie mógł on go odzyskać wyłącznie własnymi siłami. Istniała konieczność Bożego działania. Bóg nie zmienił swojego planu wobec człowieka i nadal pragnął, aby on był prawdziwie szczęśliwy. Chrystus pełniąc wolę Ojca przyjął ludzkie ciało i odkupił człowieka. Przywrócił mu nie tylko raj, ale otworzył mu dostęp do nieba, czyli do stanu najwyższego szczęścia. Od tej pory dusza sprawiedliwego człowieka, gdy tylko doświadczy cielesnej śmierci, zostaje przyjęta do rzeczywistości niebiańskiego szczęścia, której nigdy nie opuści. W przyszłości po zmartwychwstaniu sprawiedliwi ludzie będą doświadczać niebiańskiego szczęścia w nieskazitelnych ciałach.

${ }^{74}$ Gregorius Magnus, Moralia XVIII 54, 91, CCL 143A, 954: „Videbimus igitur Deum, ipsumque erit praemium laboris nostri, ut post mortalitatis huius tenebras, accessa eius luce gaudeamus".

75 Por. P. Gwiazda, Życie kontemplacyjne według św. Grzegorza Wielkiego, Warszawa 2001, 185. 


\title{
THE VOCATION OF MAN TO HAPPINES IN THE TEACHING OF GREGORY THE GREAT
}

\author{
(Summary)
}

The article discusses a question of the celestial happiness as a certain state, into which, according to the teaching of Gregory the Great, the human being was called by God and which was given to him/her as a gift. From the beginning of his/her existence, the human enjoyed the happiness of paradise and could achieve, in future, the higher state of happiness, which was the celestial happiness, on the condition that he/she will be obedient to God's commandment. However, the human did not observe obedience towards God and not only did the human not achieve the higher state of happiness, but also lost the happiness of paradise. The human being, on his/ her own, could not regain the possibility of achievement of celestial happiness. The necessary condition was God's action. Creator did not change the divine plan towards the human being and still desired him/her to be happy. God accepted the human body and redeemed humanity. God restored the human being not only to the former glory of paradise, but also opened access to heaven, i. e., to the state of the highest happiness. The human person should advance spiritually during the earthly life to become apt to accept the gift of the eternal happiness. 